STUDIA PRAWNO-EKONOMICZNE, T. CXIX, 2021

PL ISSN 0081-6841; e-ISSN 2450-8179 $\quad$ s. 157-161

https://doi.org/10.26485/SPE/2021/119/8

\title{
Bożena CZECH-JEZIERSKA*
}

iD https://orcid.org/0000-0002-0735-8166

\section{ANTONI DĘBIŃSKI, MAGDALENA PYTER, WIZJONER I REALISTA. O IDZIM RADZISZEWSKIM - TWÓRCY KATOLICKIEGO UNIWERSYTETU LUBELSKIEGO, WYDAWNICTWO KUL, LUBLIN 2020, SS. 138, ISBN: 978-83-8061-810-7}

Recenzowana publikacja Wizjoner i realista. O Idzim Radziszewskim - twórcy Katolickiego Uniwersytetu Lubelskiego ma z kilku względów szczególny charakter. Przede wszystkim z racji jubileuszowej - lubelska uczelnia obchodziła niedawno setną już rocznicę powołania do życia. W 1918 r. powstał Uniwersytet Lubelski (w 1928 r. przemianowany na Katolicki Uniwersytet Lubelski). Rok 2018 obfitował zatem w rozmaite, $\mathrm{z}$ dużym rozmachem podejmowane inicjatywy upamiętniające to wydarzenie na różne sposoby. Wśród nich znalazła się również realizacja idei uhonorowania swojego założyciela ks. Idziego Radziszewskiego poprzez wybudowanie pomnika ufundowanego w imieniu społeczności akademickiej KUL. Dokładnie w setną rocznicę powstania KUL, 8 grudnia 2018 r., nieopodal Uniwersytetu został odsłonięty pomnik pierwszego rektora uczelni i twórcy akademickiego Lublina, wzniesiony według projektu prof. Jerzego Fobera. Pomysłodawca i pierwszy rektor KUL, a jednocześnie prekursor idei lokalizacji szkolnictwa wyższego w Lublinie, którym był ks. Idzi Radziszewski, doczekał się niedawno również, recenzowanego w tym miejscu, wydawnictwa wpisującego się w cykl publikacji związanych z obchodzonym jubileuszem. Autorami książki o nim są historycy prawa: prof. dr hab. Antoni Dębiński, do 2020 r. rektor KUL, oraz dr hab. Magdalena Pyter, prof. KUL, pracownik naukowy Wydziału Prawa, Prawa Kanonicznego i Administracji tej uczelni. Wydawnictwo jest bogato ilustrowaną publikacją, zawierającą prezentację osoby ks. Idziego Radziszewskiego i jego życiorysu oraz uwarunkowań

* Dr, adiunkt w Katedrze Prawa Rzymskiego, Wydział Prawa, Prawa Kanonicznego i Administracji Katolickiego Uniwersytetu Lubelskiego Jana Pawła II; e-mail: bozena.czech-jezierska@kul.pl 
historycznych mających wpływ na organizację uniwersytetu. Łączy w sobie atrybuty albumu z wartościami opracowań biograficznych.

Osoba pierwszego rektora KUL była już uprzednio przedmiotem zainteresowania badaczy, w tym miejscu wspomnieć należy przede wszystkim dr hab. Grażynę Karolewicz, prof. KUL, która, zajmując się szeroko historią KUL i biografistyką jego środowiska, stworzyła kilka opracowań dotyczących również ks. Radziszewskiego. Teraz otrzymujemy pierwszą publikację tak obszernie traktującą o tej ważnej dla Lubelszczyzny postaci i czyniącą to jednocześnie w sposób nietuzinkowy. Przyjęta przez Autorów koncepcja książki odbiega bowiem od ujęcia stereotypowego. Taki był niewątpliwie zamysł twórców publikacji i udało im się go z powodzeniem zrealizować. O tych intencjach można zorientować się, wnioskując już z brzmienia jej tytułu, jak również dostrzec je w spisie treści i nieszablonowych tytułach rozdziałów. Na dalszych stronach czytelnik otrzymuje nie tylko relację faktograficzną dotyczącą biografii twórcy KUL, ale również szeroką panoramę historyczną ujmującą tło, miejsca i napotykane postaci. Ukazana jest ona dla poszerzenia perspektywy, co ułatwia poszukiwanie przyczyn ukształtowania ks. Radziszewskiego na śmiałego kreatora odważnych i wizjonerskich idei. Pogłębienie tych obserwacji nie jest bynajmniej nużące nawet dla niewprawionego w tekstach naukowych odbiorcy. Śledzi on zaciekawiony spory fragment historii Polski, będącej wówczas pod zaborami, a w szczególności jej wschodnich kresów. Dzieje te przedstawiono w syntetyczny i bardzo przystępny sposób, choć jednocześnie literackim i pełnym zaangażowania językiem. Dzięki malarsko i poetycko nakreślonym pejzażom miejsc ważnych dla bohatera publikacji: od bratoszewickich pól, poprzez styl budynków sakralnych, klimat murów, w których się kształcił i w których pełnił różne funkcje, po atmosferę miast, w których się znajdował na różnych etapach życia, czytelnik może lepiej zrozumieć czynniki formujące jego mentalność.

Autorzy postanowili przybliżyć postać twórcy KUL, rozpoczynając od opisu miejsca jego urodzenia oraz kontekstu historycznego i kulturowego, mającego wpływ na całe jego życie. Pierwszy rozdział zatytułowano Bratoszewice: „Dziecko na chrzcie otrzymało imię Idzi Benedykt”. To niewątpliwie ważny czas dla ukształtowania charakteru chłopca urodzonego, jako drugie dziecko, w niewielkiej miejscowości w okolicach Łodzi w $1871 \mathrm{r}$. w czasach nasilającej się rusyfikacji. Wychowany został w wielodzietnej rodzinie (czterech braci i siostra), zmuszonej do częstej zmiany miejsca zamieszkania w wyniku szykan, jakie stosowały władze rosyjskie wobec jego ojca, nauczyciela, niewystarczająco znającego język rosyjski. Czytelnik zadaje sobie pytanie: jak nieprzeciętna w swych staraniach wychowawczych i edukacyjnych musiała być ta skromna rodzina, skoro, poza późniejszym 
rektorem KUL, wychowała jeszcze dwóch innych profesorów uniwersyteckich, w tym drugiego rektora (Politechniki Warszawskiej - kierownika Katedry Wodociągów i Kanalizacji na Wydziale Inżynierii Wodnej, prof. Ignacego Radziszewskiego oraz zmarłego przedwcześnie, bo tuż po objęciu obowiązków kierownika Katedry Mineralogii i Petrografii w USB w Wilnie - prof. nadzw. Pawła Radziszewskiego). Tak odmienne dziedziny nauki, różne uczelnie, a jednocześnie łącząca niewątpliwie trzech braci odwaga $\mathrm{w}$ realizacji własnych zamierzeń, pracowitość i konsekwencja dążeń musiały mieć korzenie w domu rodzinnym.

Dalej czytelnik poprowadzony zostaje w świat kształtujący światopogląd i postawę młodego Idziego: w rozdziale drugim (Włocławek: Schola Aegidiana) otrzymujemy opis edukacji i atmosfery seminaryjnej, a w trzecim (Petersburg: kontynuacja studiów teologicznych) - początek ważnego etapu petersburskiego, gdzie w Akademii Duchownej studiował ks. Idzi, skierowany tam przez swoich przełożonych. Warto przy tym dodać, że zadecydowały o tym jego indywidualne cechy, Akademia nie była bowiem dostępna dla wszystkich, a jedynie dla najzdolniejszych seminarzystów. Następnie młody ksiądz podjął studia w Institut Superieur de Philosophie w Belgii, w Leuven, w prowincji Brabancja Flamandzka (rozdział: Lowanium: Uniwersytet lowański jest uczelnia czyniaca ,wyznanie wiary i nauki"), nie zdając sobie wówczas sprawy, w jaki sposób ten niedługi okres wpłynie na jego formację intelektualną i osobowość. Wkrótce dostał szansę na dalszy rozwój poprzez kierowanie włocławskim seminarium (rozdział: Włocławek: regens seminarium duchownego). Dalsza droga zaprowadziła go z powrotem do miasta, w którym wcześniej studiował - do Petersburga, i ten właśnie etap, bezpośrednio poprzedzający stworzenie uczelni w Lublinie, był niewątpliwie najbogatszy i najintensywniejszy, dlatego też poświęcono mu sporą część publikacji - rozdział szósty: Miasto nad Newą: „,[...] pólnocnych krain dziw i chwała”, a w nim cztery części: Academia Petropolitana: „[...] godność rektora Imperatorskiej Rzymskokatolickiej Duchownej Akademii", Wśród petersburskiej Polonii: „obdarzony wnikliwym umystem”, Historyczne spotkanie: „Myśl o katolickim uniwersytecie nie opuszczała go" oraz Komitet Organizacyjny: wybuduje gmachy Uniwersytetu w Lublinie. W tym miejscu warto dodać, że czytelnikowi przedstawiono również sylwetki głównych fundatorów KUL i jednocześnie interesujących historycznie postaci - Karola Jaroszyńskiego i Franciszka Skąpskiego. Ostatni rozdział (Lublin: ,,Siedzę w tym cudnym dla oka Koźlim Grodzie”) przybliża czytelnikowi trud zorganizowania KUL i rolę, jaką w tym odegrał ks. Idzi Radziszewski. Otrzymujemy obraz Lublina z początków XX w., pod rządami rosyjskimi i austriackimi oraz podczas powstania rządu Ignacego Daszyńskiego. Zostajemy w kolejnych częściach rozdziału przeprowadzeni wraz 
z organizatorami uniwersytetu przez wszelkie trudności, które napotykali - od lokalowych, poprzez formalne i finansowe (części: Tymczasowa siedziba uczelni: ,Roboty w gmachu uniwersytetu postępuja naprzód”, Uniwersytet Lubelski: „Instituatur praeside praelato Aegidio Radziszewski”, Koszary świętokrzyskie: „,Wielki i doskonały gmach $w$ wyśmienitym punkcie miasta”) i w końcu tak istotne kwestie uprawnień do nadawania stopni naukowych, kadry i programów nauczania (Początki działalności: ,jak dobry ojciec [...] wskazuje cele wzniosłe i szlachetne, zagrzewa do pracy, budzi umysty i serca"). Krótko nacieszył się pierwszy rektor KUL swoim dziełem. Zmarł młodo, bo mając niewiele ponad pięćdziesiąt lat, 22 lutego 1922 r., na zapalenie płuc, a jego pogrzeb stał się żałobną i jednocześnie uroczystą manifestacją społeczności akademickiej i miejskiej Lublina, wyrażającą uznanie dla wkładu, jaki ks. Radziszewski miał w rozwój Koziego Grodu (Ostatnia droga: „Życie swoje rozumiat jako nieprzerwany ciag znojnej, bezlitosnej pracy"). W Zakończeniu, któremu przydano podtytuł Uniwersytet jest dzieckiem swoich czasów, Autorzy uwidocznili dalekosiężne skutki realizacji wizji ks. Radziszewskiego i jego śmiałych decyzji, szkicując współczesny obraz uczelni. Nie zapomniano również o naukowej działalności twórcy KUL, zamieszczając wykaz jego publikacji.

Integralną częścią wydawnictwa, wpływającą na jego oryginalność i podnoszącą znacząco walory estetyczne, są zarówno kolorowe, jak i czarno-białe fotografie oraz skany uzupełniające wywód Autorów. Bogato ilustrują one poszczególne części, uzupełniając plastyczne opisy i dając możliwość spojrzenia na pejzaże miejsc, wizerunki osób, dokumenty, zarówno okiem współczesnego, jak i dawnego obserwatora, przez co obraz tworzony sobie przez czytelnika jest niewątpliwie pełniejszy. Trzeba tu podkreślić, że jest to niejednokrotnie materiał nigdzie wcześniej niepublikowany.

Autorzy wykorzystali w tym celu zasoby Archiwum KUL, Biblioteki Uniwersyteckiej KUL, AAN w Warszawie, Archiwum Politechniki Warszawskiej, Rosyjskiego Państwowego Historycznego Archiwum w Petersburgu, Centralnego Państwowego Archiwum Historycznego Sankt Petersburga, Litewskiego Centralnego Archiwum Państwowego w Wilnie, jak również uzyskali dostęp do archiwum rodzinnego Jaroszyńskich z Krakowa. Umożliwili czytelnikowi wgląd nawet $\mathrm{w}$ fotografie wykonane przez ówczesnego studenta prawa $\mathrm{z}$ początkowego okresu działania uniwersytetu. Takie właśnie perełki tworzą klimat całej publikacji. Cała jej elegancka szata graficzna, kompozycja oraz przejrzysty układ treści sprawiają, że książkę z przyjemnością bierze się do rąk i tak też się ją czyta.

Drobiazgowa wręcz pieczołowitość, z jaką Autorzy przygotowali publikację, obliguje jednakże również recenzenta do takiegoż potraktowania ich dzieła. 
Rzetelność zatem nakazuje wskazanie przeoczenia, jakim niewątpliwie stał się brak w przypisach i bibliografii jedynego najpełniejszego i powszechnie znanego społeczności akademickiej KUL opracowania biograficznego o ks. Idzim Radziszewskim autorstwa wspomnianej już G. Karolewicz Ksiadz Idzi Benedykt Radziszewski 1871-1922, Wyd. POLIHYMNIA, Lublin 1998, ss. 164 oraz późniejszej broszurki jej autorstwa Ksiadz Idzi Benedykt Radziszewski i jego dzieto - Katolicki Uniwersytet Lubelski, Wyd. POLIHYMNIA, Lublin 2000, ss. 31. Co prawda, Autorzy przywołali sześć innych pozycji tematycznych G. Karolewicz, niemniej powinni byli wskazać czytelnikowi jej monografię o twórcy KUL.

W 2020 r. upłynęło 20 lat od momentu wybrania ks. Idziego Radziszewskiego Lublinianinem Stulecia. Postać ta niewątpliwie zasługuje więc na pięknie wydane wspomnienie biograficzne. Jednakże nie tylko społeczność lubelska będzie stanowić zainteresowane nim grono. Część jego życiorysu związana jest również z Petersburgiem, zatem Polonię zza wschodniej granicy naszego kraju usatysfakcjonuje zapewne wydanie rosyjskie tej publikacji (Визионер и реалист. Об Эгидии Радзишевском - создателе Католического университета в Люблине, Lublin 2021). Natomiast fakt, iż przetłumaczono ją również na język angielski (A Visionary and Realist. Idzi Radziszewski Founder of the Catholic University of Lublin, Wyd. KUL, pp. 138) oraz wydano we Włoszech (Visionario e realista. Idzi Radziszewski - fondatore dell'Università Cattolica di Lublino, ed. Sette Città, Viterbo 2020, pp. 210) stanowi czynnik sprzyjający rozpropagowaniu jej treści poza granice Polski.

Charakter publikacji sprawia, że pomimo nabrania cech opracowania naukowego poprzez opatrzenie aparatem naukowym, posiada ona również przymioty wydawnictwa popularyzującego szerokiemu gronu odbiorców postać „Lublinianina Stulecia” oraz historię lubelskiej uczelni i rolę, jaką odegrał jej pierwszy rektor. Wrażenie to jest spójne z zamierzeniami Autorów, którzy piszą:

\footnotetext{
Ufamy, że publikacja, którą oddajemy do rąk Czytelników, przybliży sylwetkę pierwszego rektora lubelskiej uczelni, jego niezwykłe i pełne poświęceń starania o utworzenie uniwersytetu. Wyrażamy także przekonanie, że zapoznanie się z losami i działalnością tego niezwykłego wizjonera utwierdzi wszystkich biorących tę książkę do ręki w przekonaniu, że warto realizować wielkie zamierzenia i idee, nawet jeśli gdzieś w tle majaczą niesprzyjające okoliczności losu.
}

Należy zatem pogratulować Autorom skutecznej i pełnej rozmachu realizacji idei wydawniczej, nawet wbrew okolicznościom losu, niesprzyjającym obecnie aktywności naukowej w rzeczywistości borykającej się z pandemicznym paraliżem. 